\title{
The coming of the railways to Russia, Mikhail Glinka
}

THe RAILWAY NETWORK in Russia was slower to be established than in most parts of Europe. The first railway line was the result of a royal initiative; Tsar Nicholas I wished to connect two royal palaces, his main residence in $\mathrm{St}$ Petersburg and the summer residence, which had been favoured by Catherine the Great, in Tsarkoe Selo. The line was completed in 1837 and on October 30th the train was driven by Franz Anton von Gerstner, the Austrian engineer who had built the line 'with a huge audience of ministers and officials.' Christian Wolmar writes of the opening of the St Petersburg to Tsarkoe Selo line that the first train 'carrying eight full coaches' took a 'mere 28 minutes to reach Tsarkoe Selo an impressive average speed of almost $50 \mathrm{kph}(30 \mathrm{mph})$ '. The following year the line was extended by 16 miles beyond St Petersburg in order to connect it to Pavlosk, the fashionable entertainment resort. The line was a great success drawing the crowds through both their curiosity to see the new railway and their desire to experience the new attractions. The 400 mile line from St Petersburg to Moscow was completed in 1851 becoming one of the longest trunk routes in the world. Partly designed to act as defence barrier, the Russian lines were built to a broad track gauge rather than the narrow standard gauge found in most of Europe. ${ }^{2}$

'The travelling song' (1940) by the Russian composer Mikhail Glinka is often claimed to be the first railway song. 


\section{Mikhail Glinka}

Mikhail Ivanovich Glinka (1804-1857), the first Russian composer of any stature, is best known for his two operas A Life for the Tsar (1836) and Ruslan and Lyudmila (1842). The son of an army captain, Glinka grew up in a wealthy family in Novospasskoye in the district of Smolensk. There he had his first contact with music listening to Russian folksongs and church choirs as well as performing himself in various local ensembles, mainly on piano and violin. His family were over-protective of him as a child and he was often cooped up inside rooms with too high a temperature. This may have led to his life of suffering from, and worrying about, his numerous ailments. In short he was a hypochondriac.

For much of his life he travelled around Europe with extensive stays in Italy, Germany, Poland, France and Spain. He counted many artists among his friends including the French composer Berlioz, the Italian opera composers Bellini and Donizetti, and the Russian writers Pushkin and Kukolnik. Although he was influenced by the music he came across, notably the music of Spain as well as Italian and French opera, his compositions were also imbued with Russian folksong and often used Russian themes as their subject matter. His first opera, A Life for the Tsar, came about as a result of his resolve to create an opera with a clear Russian sensibility, in the same way that the operas of his contemporaries Donizetti and Bellini were quintessentially Italian. It was premiered in the presence of the Imperial family in November 1836 and was an immediate success. Unfortunately that was not the case with his much-anticipated second opera Ruslan and Lyudmila which, with its more adventurous music, including Persian and Turkish influences, proved to be too exotic for the St Petersburg audience. Unsurprisingly Glinka was very disappointed and from then on focused less on composing and more on his European travels. Two years before he died he was persuaded by his sister to write the story of his life which is now entertainingly documented in his Memoirs. ${ }^{3}$

It is not clear when Glinka first travelled by train. He travelled widely, but in his Memoirs he makes scant reference to railway journeys although there is much attention paid to the types of carriages he travelled on by road, the many women he found attractive and the ailments he was currently suffering from. What he does write about journeys by rail would indicate that he was not greatly enamoured by that means of travel. In 1852 he travelled from Paris to Chalon-sur-Saône by railroad and he records that "... during the journey, I 
suffered for several hours from a nervous sinking or fainting sensation with feelings of terror. ${ }^{4}$ Similarly he writes that in the spring of 1853 he wished to return home from Paris but the railroad frightened me and I was trying to find some other way of travelling.'

\section{'The travelling song' No. 6 from A Farewell to St. Petersburg - Mikhail Glinka and Nestor Kukolnik}

'The travelling song' is No. 6 of Glinka's cycle of twelve songs (or romances), A Farewell to St Petersburg. The cycle is written for voice and piano and has words by the Russian writer Nestor Kukolnik. According to David Brown, who wrote the standard text on Glinka, its title was 'prompted by Glinka's own wish to get away from the capital' at a time when he was experiencing various personal problems, not least the disintegration of his marriage. The complete volume of twelve songs was written quickly without much difficulty as Glinka writes in his Memoirs,

The melody of the bolero $O$ beautiful maid of mine came to mind ...I asked Kukolnik to write some lines for this new melody and he agreed, at the same time offering me some other romances he had written...I had several spare melodies, so the work went along very well, I must say. ${ }^{6}$

According to Brown, in the case of 'The travelling song', the music was written before Kukolnik added the words. ${ }^{7}$ A Farewell to St Petersburg provides a good illustration of what the Grove Dictionary of Music describes as Glinka's 'eclectic absorption of contemporary western techniques and idioms. ${ }^{8}$ Some of the songs have a Russian flavour, one or two have a Spanish influence whilst others have their roots in Italian music. Brown argues that 'The travelling song' owes something to Italian opera buffa (comic opera). ${ }^{9}$ He has also been known to refer to it as an 'opera buffa puffer' and to describe it as a 'patter piece'. It is true to say that it displays several features of a patter song - a form often found in comic operas, particularly those of Gilbert and Sullivan. It has a fast tempo and a rapid succession of rhythmic patterns in which each syllable of the text corresponds to one note. The lyrics feature entertaining tongue twisting rhymes and the piano accompaniment is light and fairly simple in order to emphasise the words. It would also be true to describe it as a perpetuum mobile - a continuous stream of notes played at a rapid tempo. 
The song is marked presto (very fast) and the tempo never wavers, travelling at top speed throughout, reflecting the speed generated by the locomotive engine. It is in a simple form (ABABA) where the refrain (A) alternates with the two verses (B). The opening refrain rattles away, two beats in a bar, in the bright key of $\mathrm{D}$ major as the train rushes through the countryside. The simple piano accompaniment has a straightforward rhythm and few chord changes with loud accented chords marking the end of each phrase.

The smoke is boiling, the steamer is smoking!

Diversity, revelry, excitement, anticipation, impatience!

Our Orthodox people rejoice

And faster, faster than will, the train rushes in an open field. ${ }^{10}$

In contrast with the refrain, the verse has a more lyrical character as the words tell of the anticipation of the journey's end. The minor key reflects the wistful mood of the words and the melody rises and falls against a background of colourful chords.

No, the secret thought flies faster,

And the heart beats counting the moment.

Insidious thoughts flicker along the road,

And you whisper involuntarily: How long, how long?

Finally - two myths to be dispelled. It is often written that 'The travelling song' was composed to celebrate the inauguration of the St Petersburg to Tsarkoe Selo line, but no direct link can be found to substantiate this. Furthermore it was written three years after the event. Nevertheless it is safe to assume that the new locomotives and the railway aroused much excitement at the time, in the same way as they had across Europe. The song is also often cited as being either the first railway song or the first piece of railway music, however, given that it was composed in 1840 this is not strictly true. In terms of songs, several British broadside ballads telling of railway building and railway openings were around by then (see Chapter 1) and one of the most famous Strauss railway pieces, Eisenbahn-Lust-Walzer (Railway pleasure waltzes), had been composed four years before. It might be more accurate to say that 'The travelling song' was the first art song to be written about the railway or indeed the first piece of Russian railway music. 


\section{Endnotes}

1 Christian Wolmar. The Golden Age of European Railways. (Barnsley: Pen \& Sword Transport, 2013): 217.

2 Christian Wolmar. A Short History of Trains. (London: Dorling Kindersley Ltd., 2019): 46-49.

3 Mikhail Ivanovich Glinka. Memoirs. Translated by Richard B Mudge. (Norman: University of Oklahoma Press, 1963).

4 Glinka, Memoirs, 231-2.

5 Glinka, Memoirs, 236.

6 Glinka, Memoirs, 150.

7 David Brown. Mikhail Glinka. A Biographical and Critical Study. (London: Oxford University Press, 1974): 159.

8 Stuart Campbell, 'Glinka, Mikhail Ivanovich' in Grove Music Online.

9 Brown, Mikhail Glinka, 159.

10 The song translation is by Peter Owens. As far as the different languages allow, it aligns the English words with their Russian equivalents in the original text. 
10.5920/railways.9 